\title{
PELAKSANAAN PERLINDUNGAN HUKUM BAGI TENAGA KERJA OUTSOURCING BERDASARKAN UNDANG-UNDANG REPUBLIK INDONESIA NO. 13 TAHUN 2003 \\ Oleh: \\ Umi Kholifah \\ Praktisi Hukum di Semarang
}

\begin{abstract}
ABSTRAK
Pasal 64 Undang-undang Republik Indonesia No. 13 Tahun 2003 tentang Ketenagakerjaan secara tidak langsung mengijinkan outsourcing yaitu "Perusahaan dapat menyerahkan sebagian pelaksanaan pekerjaan kepada perusahaan lainnya melalui perjanjian pemborongan pekerjaan atau penyediaan jasa pekerja/buruh yang dibuat secara tertulis. Sebelumnya ada peraturan yang mengatur tentang kesepakatan kerja waktu tertentui yang hanya mengatur aspek kerjanya saja, yaitu Peraturan Mentri Tenaga Kerja No. 02/11/1993.

Tenaga kerja outsourcing mempakan pihak yang paling dirugikan, karena apabila terjadi pemutusan hubungan kerja oleh perusahaan, maka tenaga kerja outsourcing tidak mendapatkan hak normatif. Tumbuh suburnya outsourcing dipandang oleh pemerintah perlu adanya peraturan agar pihak-pihak yang terlibat tidak ada yang dirugikan, khususnya tenaga kerja outsourcing. Ketentuan Pasal 6 Undang- Undang Republik Indonesia No. 13 tahun 2003 menyatakan: "Setiap pekerja/buruh berhak memperoleh perlakuan yang sama tanpa diskriminasi dari pengusaha". Dengan demikian, setiap pekerja terhak memperoleh perlakuan yang sama tanpa perbedaan dari pengusaha, tinggal bagaimana pengusaha dalam merealisasikannya, namun kenyataannya masih banyak hak tenaga kerja outsourcing yang tidak diberikan sebagaimana hak tenaga kerja lainnya, seperti Jaminan sosial tenaga kerja, pesangon dalam hal PHK, uang penghargaan masa kerja, uang pengganti pengobatan dan uang pengganti cuti tahunan.
\end{abstract}

Kata Kunci: Perlindungan Hukum, Tenaga Kerja Outsourcing, Undang-Undang No. 13 Tahun 2003

\begin{abstract}
Article 64 of Act No.13 of 2003 on Labor indirect ‘allows outsourcing: "Connies may subcontract part of tbe work to another company through an agreement of construction work or the provision of worker/ labor made in written". Previously, there was a reflation governing the agreement of partiadar time work which only set to work aspect, name sthe Reflation of the Minister of Manpower No. 02/Mroi/1/1993.

Outstmrcing workers are the most harmed party because in the event of termination of employment by the company, the outsourcing did not obtain their normative rights. Concerning the rapid growth of outsourcing, the government considers to make a law in order that no parties involved are harmed particular the outsourcing labor. The provision of Article 6 of Act No. 13 of 2003 states: 'Any worker/ labor is entitled to equal treatment wtthmit discriminationfkom employers". 'IRus, each worker are entitled to equal treatment without discrimination from employers; just how employers realize it. However, in reali there are many rights of outsourced workers are not given as labor righte, such as socktl security workers, SCTerance pay in the event of lay., gratuity fee,
\end{abstract}


the substrates fee as the replacementfor medication, and annual leave.

Keywords : Legal Protection, Outsourcing labor. Act No. 13 of 2003

\section{A. Pendahuluan}

Undang-undang

Republik

Indonesia No. 13 Tahun 2003 tentang

Ketenaga kerjaan tidak menyebutkan secara tegas mengenai istilah outsourcing, namun dalam Pasal 64 secara tidak langsung disinggung mengenai outsourcmg yaiu 'Perusahaan dapat menyerahkan sebagian pelaksanaan pekerjaan kepada perusahaan lainnya melalui perjanjian pemborongan pekerjaan atau penyediaan jasa pekerja/buruh yang dibuat secara tertulis. Sebelum diundangkan Undang-undang Republik Indonesia No. 13 Tahun 2003 tentang Ketenagakerjaan, belum ada peraturan yang mengatur tenteng outsourcing, yang ada setelumnya hanyalah Peraturan Mentri Tenaga Kerja No. 021N/I/1993 tentang Kesepakatan Kerja Waktu tertentu yang hanya mengatur tentang aspek kerjanya saja.

\section{Walaupun}

outsourcing

merupakan sebuah sistem kontrak yang diadopsi dari Undang-undang Republik Indonesia No. 13 Tahun 2003 tentang ketenagakerjaan, namun ada yang terpendapat bahwa sistem kontrak outsourcing sangat melemahkan posisi buruh. Dengan sistem ini, kalangan pengusaha berhak untuk memberhentikan buruh dengan alasan kontrak diputuskan. Outsourcing memungkinkan pengusaha melakukan pemberhentian kapanpun karena alasan perekonomian. Ini benar-benar merugikan buruh. Dari data yang diperoleh, 80\% lebih buruh di Kawasan Industri Medan (KIM), Mabar (Sumut), direkrut melalui kontrak masa berlakunya bisa hanya 3 tahun saja. Sementara gaji yang diberikan sama dengan hak-hak normatif.' ${ }^{1}$

Sebagainana diketahui, outsourcing dimungkinkan untuk mengerjakan pekerjaan yang tersifat penunjang. Sementara, kegiatan yang tersifat pokok mestinya tidak di outsourcingkan Undang-undang ini tidak memberikan sanksi yang tegas terhadap pengusaha yang melanggarnya. Ratusan konflik buruh versus majikan juga tidak terselesaikan secara adil Ada

\footnotetext{
${ }^{1}$ (http://en.wikipedia.org/wiki/outsourcing) Diakses tanggal 10 juni 2010
} 
banyak kasus yang sudah berjalan bertaun- tahun tetapi belum juga menemukan titik penyelesaian, Selain menggunakan sistem kontrak kerja dalam waktu tertentu, perusahaan juga menggunakan sistem kerja borongan. Sistem kerja yang dipergunakan oleh perusahaan untuk mengimbangi pesanan konsumen dalam jangka waktu tertentu dengan jumlah yang banyak.

\section{Dikeluarkannya Undang-Undang} Republik Indonesia No. 13 Tahun 2003 tentang Ketenagakerjaan, mempunyai arti bahwa Negara Indonesia telah mempunyai suatu produk hukum yang mengatur secara lengkap dan menyeluruh. Undang-Undang ini disanding untuk mencabut ketentuan yang tidak sesuai lagi dengan tuntutan dan perkembangan zaman, dimaksudkan juga untuk menampung perubahan yang sangat mendasar disegala aspek kehidupan bangsa Indonesia dengan dimulainya era reformasi 1998. Namun di lapangan ternyata masih terdapat penolakan pemberlakuan undang-undang baru ini oleh beberapa serikat pekerja atau serikat buruh salah satunya menyangkut masalah pemotongan pekerjaan.

Sistem outsourcing menjadi kebutuhan nyata pada berbagai jenis bidang usaha tertentu karena terdapat beberapa jenis pekerjaan yang walaupun merupakan bagian integral dari proses produksi tetapi menurut sifatnya dan berdasarkan pertimbangan ekonomi perusahaan lebih tepat jika dikerjakan oleh pekerja dalam hubungan kerja outsourcing. $^{2}$

Tenaga kerja outsourcing merupakan pihak yang paling dirugikan dalam suatu perjanjian kerja, karena apabila terjadi pemutusan hubungan kerja oleh perusahaan, maka tenaga kerja outsourcing tidak mendapatkan hak-hak normatif sebagaimana layaknya tenaga kerja tetap, walaupun masa kerja sudah bertahun-tahun. Masa kerja tidak merupakan faktor penentu, karena tiap tahun kontrak kerjasama dapat diperbaharui, sehingga masa pengabdian dimulai lagi dari awal saat terjadi perjanjian kontrak kerja antara perusahaan dengan buruh.

Pelaksanaan

Outsourcing melibatkan 3 (tiga) pihak yakni perusahaan penyedia tenaga kerja outsourcing, perusahaan pengguna tenaga kerja outsourcing, dan tenaga

\footnotetext{
2 P.Rajaguguk, 27 mei 1994,Ketenagakerjaan Makalah Seminar Hukum Ketenagakerjaan Dalam Rangka Pendayagunaan Pembina dan Perlindungan Tanpa kerja di Departemen Tenaga Kerja,Jakarta.
} 
kerja outsourcing itu sendiri. Tumbuh suburnya outsourcing di masyarakat dipandang oleh pemerintah perlu adanya suatu peraturan agar pihak-pihak yang terlibat tidak ada yang dirugikan khususnya tenaga kerja outsourcing. Maka dalam Pasal 64-66 Undang-Undang Republik Indonesia No. 13 Tahun 2003 mengatur mengenai pelaksanaan outsourcing.

Dalam rangka memberikan perlindungan tenaga kerja dengan waktu tertentu atau tenaga kerja kontrak outsourcing, maka ketentuan Pasal 6 Undang-Undang Republik Indonesia No. 13 tahun 2003 tentang Ketenagakerjaan menyatakan: "Setiap pekerja/buruh berhak memperoleh perlakuan yang sama tanpa diskriminasi dari pengusaha". Berdasarkan Pasal 6 Undang-Undang Republik Indonesia No. 13 tahun 2003, maka setiap pekerja buruh berhak memperoleh perlakuan yang sama tanpa perbedaan dari pengusaha, tinggal bagaimana pengusaha dalam merealisasikannya, namun kenyataannya masih banyak hak tenaga kerja outsourcing yang tidak diberikan sebagaimana haknya tenaga kerja lainnya, seperti Jaminan sosial tenaga kerja, pesangon dalam hal PHK, uang penghargaan masa kerja, uang pengganti pengobatan dan uang pengganti cuti tahunan.

Permasalahan perlindungan tenaga kerja dalam pelaksanaannya masih jauh dari harapan. Hal ini terbukti dalam praktik ketenagakerjaan, masih terdapat hal-hal yang tidak sesuai dengan yang telah ditetapkan dalam Undang-Undang Ketenagakerjaan, dimana pengusaha masih banyak membuat peraturan sendiri untuk kepentingan perusahaan tanpa memperdulikan apa yang menjadi hak-hak para tenaga kerjanya. Oleh karena itu, penulis ingin mengkaji lebih dalam tentang "Pelaksanaan Perlindungan Hukum Bagi Tenaga Kerja Outsourcing Berdasarkan Undang-Undang Republik Indonesia No. 13 Tahun 2003 Tentang Ketenagakerjaan.

\section{B. Permasalahan}

1. Bagaimana pelaksanaan perlindungan hukum bagi tenaga kerja outsourcing berdasarkan Undang-Undang Republik Indonesia Nomor 13 Tahun 2003 Tentang Ketenagakerjaan.

2. Bagaimana hambatan dalam pelaksanaan perlindungan hukum bagi tenaga kerja 


$\begin{array}{lr}\text { outsourcing } & \text { berdasarkan } \\ \text { Undang-Undang } & \text { Republik } \\ \text { Indonesia Nomor } 13 \text { Tahun } 2003 \\ \text { Tentang Ketenagakerjaan }\end{array}$

\section{Pembahasan}

\section{Perlindungan Hukum Bagi Tenaga} Kerja

Hubungan kerja melalui outsourcing merupakan upaya untuk menyiasati hukum, baik sebelum lahirnya Undang-Undang Republik Indonesia No 13 tahun 2003 maupun sesudahnya. Meskipun undang-undang yang baru secara implisit tidak membenarkan hubungan kerja seperti itu untuk pekerjaan yang sifatnya permanen atau terus menerus dan hanya dibenarkan untuk pekerjaan tertentu serta dengan jangka waktu yang tidak lebih lama dari yang ditentukan undang-undang, akan tetapi masih dapat disiasati dengan berbagai cara penetapan ketentuan job discription dan jangka waktu yang diputus-putus serta dengan penggantian nama perusahaan outsourcing.

Para karyawan outsourcmg ini memang tidak banyak punya pilihan lain di mana pengangguran terbuka secara nasional melebihi 11,6 juta orang, pengangguran tertutup 30 juta orang dari penawaran tenaga kerja lebih dari 106.9 juta orang. ${ }^{3}$ Sementara itu banyak pula perusahaan yang tutup karena kalah bersaing dengan produk import, sedangkan produk ekspor juga menurun karena biaya produksi yang tinggi di dalam negeri Mereka juga terpaksa harus menerima nasib yang lebih buruk dari 11.000 karyawan yang berdemo di Surabaya menuntut kenaikan upah minimum regional Kepada siapa mereka dapat menuntut karena perusahaan penyedia tenaga kerja itu tidak punya aset dan setiap saat dapat tutup dan ganti nama perusahaan lain.

Tenaga outsourcmg ini perlu diberikan perlindungan hukum karena alasan menyelematkan angkatan kerja work force yang sangat potensial satu dan lain hak untuk melakukan gerak kemajuan ekonomi secara umum. Kebanyakan dari tenaga kerja outscourcing ini adalah profesional di bidangnya, muda dalam usia, dan mempunyai semangat kerja yang baik. Kekurangan mereka kebanyakan adalah karena tidak mempunyai kesempatan dan tidak mempunyai hubungan khusus dengan para penentu kebijaksanaan perusahaan. Mereka juga datang

\footnotetext{
${ }^{3}$ http://en.wikipedia.org/wiki/outsourcing
} 
belakangan dibandingkan dengan tenaga tetap karena memang mereka juga belakangan datangnya di dunia. Angkatan kerja potensial ini perlu dilindungi juga dengan alasan bilamana gerak pembangunan ekonomi bangsa mulai berjalan lagi maka tenaga kerja ini tetap tersedia dan siap menyambut gerak pembangunan kembali ekonomi Indonesia paskta krisis. Kenyataan di negara maju menunjukkan bahwa bagaimanapun modemnya proses produksi, tetap saja diperlukan operator yang handal dan bersemangat tinggi sehingga mereka masih tetap dipekerjakan sampai sekarang. Menurut Newsweek 30 Januari 2006 harus mempekerjakan tenaga-tenaga yang sudah berumur lanjut.

$$
\text { Meskipun undang-undang }
$$

ketenagakerjaan yang paling baru telah mengatur, namun demikian masih juga terdapat beberapa celah yang dapt dimanfaatkan. Dalam masalah pemanfaatan celah inilah maka pada umumnya pihak perusahaan penyedia tenaga kerja menunjukkan kepiwaiannya. Kedudukan pekerja selalu berada dalam posisi yang lemah, baik dihadapan perusahaan penyedia tenaga kerja maupun dihadapan perusahaan pemakai tenaga kerja.
Karena para pekerja berasal dari berbagai tempat dan kebanyakan bekerja dalam waktu yang terbatas yakni rata-rata 3 tahun maka tentu saja mereka tidak mudah untuk berorganisasi Untuk masuk ke dalam organisasi pekerja tetap juga tidak mudah karena mereka biasanya juga dianggap sebagai saingan terutama bersedia menerima gaji dan hak-hak yang lebih rendah dari pekerja tetap hingga posisi tawar pekerja tetap juga goyah dihadapan perusahaan pemakai tenaga kerja. Jadi, tenaga kerja outsourcing ini menjadi tenaga kerja yang terjepit dan terpaksa menerima nasib termasuk bilamana tiba- tiba harus berhenti karena pemberi kerja mau efisien.

$$
\text { Undang-Undang Republik }
$$
Indonesia No. 13 Tahun 2003 tentang Ketenagakerjaan tidak menyebutkan secara tegas mengenai istilah dari outsourcing, namun dalam Pasal 64 secara tidak langsung disinggung mengenai outsourcing yaitu "Perusahaan dapat menyerahkan sebagian pelaksanaan pekerjaan kepada perusahaan lainnya melalui perjanjian pemborongan pekerjaan atau penyediaan jasa pekerja/buruh yang dibuat secara tertulis. 
Pengertian outsourcing disamakan dengan perjanjian pemborongan pekerjaan. Sedangkan menurut Pasal 1601b KUH Perdata, perjanjian pemborongan pekerjaan adalah suatu perjanjian dimana pemborong mengikat diri untuk membuat suatu kerja tertentu bagi pihak lain yang memborongkan dengan menerima bayaran tertentu dan pihak yang lain yang memborongkan mengikatkan diri untuk memborongkan pekerjaan kepada pihak pemborong dengan bayaran tertentu.

Dari pengertian di atas dapat ditarik suatu definisi operasional mengenai outsourcing yaitu suatu bentuk perjanjian kerja antara perusahaan A sebagai penguna jasa dengan perusahaan $\mathrm{B}$ sebagai penyedia jasa, dimana perusahaan A meminta kepada perusahaan B untuk menyediakan tenaga kerja yang diperlukan untuk bekerja di Perusahaan A dengan membayar sejumlah uang dan upah atau gaji tetap dibayarkan oleh Perusahaan B. ${ }^{4}$

$$
\text { Undang-Undang Republik }
$$

Indonesia No. 13 Tahun 2003 tentang Ketenagakerjaan mengatur syarat-syarat

\footnotetext{
4 I Wayan Nedeng, Lokakana Dua hari, 2003, :Outsourcing dan PKWT, (PT. Lembangterang Jakarta,hlm.2)
}

perusahaan yang dapat menyediakan tenaga kerja agar kepentingan para pihak yang terlibat dalam Perjanjian Outsourcing tidak ada yang dirugikan terutama tenaga outsourcing yang biasanya berada pada posisi yang lemah. Syarat-syarat tersebut dalam Pasal 66 Undang-Undang Republik Indonesia No. 13 Tahun 2003 antara lain :

a. Ada hubungan kerja antara pekerja/buruh dengan perusahaan penyedia jasa pekerja/buruh;

b. Perjanjian kerja yang berlaku dalam hubungan kerja adalah perjanjian kerja untuk waktu tertentu yang memenuhi persyaratan sebagaimana terdapat dalam Pasal 59 Undang-Undang Republik Indonesia No. 13 Tahun 2003 dan atau perjanjian kerja waktu tak tertentu yang dibuat secara tertulis dan ditandatangani oleh kedua belah pihak.

c. Perlindungan upah dan kesejahteraan, syarat-syarat kerja, serta perselisihan yang timbul menjadi tanggung jawab perusahaan penyedia jasa pekerja/buruh;

d. Perjanjian antara perusahaan 
pengguna jasa pekerja/buruh dan penyedia jasa pekerja/buruh dibuat tertulis dan wajib memuat pasal-pasal yang dimaksud dalam undang-undang ini;

e. Penyedia jasa pekerja harus berbadan hukum dan memiliki ijin dari instansi bidang ketenagakerjaan.

Apabila ketentuan-ketentuan yang telah disebutkan di atas tidak terpenuhi, maka demi hukum status hubungan kerja antara buruh dengan perusahaan penyedia jasa pekerja beralih menjadi hubungan kerja antara pekerja/buruh dan perusahaan pemberi pekerjaan.

\section{Hak Para pekerja}

Khusus untuk melindungi pekerja dengan waktu tertentu atau tenaga kerja kontrak outsourcing maka ketentuan dalam Pasal 6 adalah ketentuan yang sangat penting untuk mempersamakan perlakuan dengan pekerja tetap. Pasal mi menentukan bahwa setiap pekerja/buruh berhak memperoleh perlakuan yang sama tanpa diskriminalisasi dari pengusaha. Tinggal sekarang bagaimana realisasi dari peraturan yang baik ini

Menurut Pasal 56, perjanjian kerja dibuat untuk waktu tertentu dan untuk waktu tidak tertentu. Untuk waktu tidak tertentu dapat juga kita sebut sebagai pekerja tetap. Sedangkan perjanjian kerja untuk waktu tertentu didasarkan atas :

$$
\begin{aligned}
& \text { Jangka waktu tertentu } \\
& \text { Selesainya suatu pekerjaan } \\
& \text { tertentu. }
\end{aligned}
$$

Kebanyakan dari para pekerja outsourcing adalah termasuk dalam perjanjian kerja untuk jangka waktu tertentu dan dimaksudkan untuk menutup kesulitan menentukan jenis pekerjaan tertentu yang dapat diselesaikan dalam waktu tertentu, misalnya mengenai pemborongan pekerjaan. Ini juga merupakan peluang yang dapat dimanfaatkan oleh perusahaan penyedia tenaga kerja dan para pemberi kerja agar mendapat tenaga murah dan berkualitas.

Bagi pekerja outsourcing sebenarnya pembedaan ini dapat dibuat, akan tetapi tidak berarti mereka tidak mengetahui tentang hak-hak dasar pekerja seperti disebutkan dalam Pasal 6 di atas, yakni hak nondiskriminasi Hak-hak dasar ini dipertegas lagi dalam berbagai pasal terikut ini:

- Pasal 35 ayat (2) UU RI No. 13 Tahun 2013 menyatakan bahwa pelaksana penempatan kerja (PJPT) wajib memberikan 
perlindungan sejak rekrutimen sampai penempataan tenaga kerja.

- Pasal 35 ayat (3) UU RI No 13 Tahun 2003 menyebutkan, pebmeri kerja dalam memperkerjakan tenaga kerja wajib memberikan perlindungan yang mencakup kesejahteraan, keselamatan, dan kesehatan, baik mental maupun fisik tenaga kerja.

Menurut formulasi Pasal 59 tentang perjanjian kerja waktu tertentu, pekerja outsourcing termasuk di datam kategori ini, sehingga para pekerja ini harus diberikan pekerjaan yang sesuai sifatnya dengan apa yang disebut dalam ayat (1) dan (2) Pasal 59 undang undang ini. Bilamana tidak sesuai, misalnya pekerjaan adminishasi perkantoran yang tidak dapat dipisahkan dengan pekerjaan rutin pegawai tetap lainnya maka demi hukum pekerja outsourcing ini harus diakui oleh pemberi kerja sebagai pekerja tetapnya dan tidak dapat didiskriminasikan dengan pekerja tetap lainya. Hal ini dipertegas lagi oleh Pasal 65 ayat (4) dan ayat (8) sehingga hak-haknya harus dipulihkan dan disamakan dengan pekerja tetep termasuk dalam hal jangka waktu kerja.
Dalam hal demikian, bilamana suasana kerja sudah tidak mengenakkan kedua belah pihak, maka pekerja mau tidak mau akan menerima pemberhentian kerja oleh pihak pemberi kerja. Bahasa yang dipakai biasanya adalah saling tampar tanggung jawab antara penyedia tenaga kerja (PJPT) dan pihak pemberi kerja. Namun setidak-tidaknya hak-hak pekerja juga harus dihormati dalam hal pemberhentian hubungan kerja, yakni hak-hak normatife untuk memperoleh pesangon dan ganti kerugian sebagaimana

Bilamana hak-hak pekerja ini tidak dipenuhi maka tuntutan pekerja ini dapat diajukan kepada mediator Dinas Tenaga dan Transmigrasi setempat dengan permohonan agar dapat diberikan perantaraan agar pihak pemberi kerja memberikan hak-hak normatif dari tenaga outsourcing yang diberhentikan oleh pemberi kerja Nasehat mediator ini dapat berupa anjuran agar pemberi kerja menjalin kembali hubungan kerja yang non diskriminatif dengan pihak pekerja atau dalam hal pekerja diberhentikan, maka diberikan hak-hak normatif seperti diberikan kepada pekerja tetap.

Bilamana anjuran ini tidak ditaati 
maka para pihak atau salah satu pihak bisa mengajukan kepada Pengadilan Hubungan Industrial melalui mekanisme gugatan yang biasanya memberikan keputusan dalam hal perselisihan pekerja dengan pemberi kerja dalam hal keputusan pemutusan hubungan kerja sebagai berikut :

- Menetepkan 2ontusnya hubungan kerja.

- Memberikan pesangon sesuai ketentuan -pasal 156 ayat (2) Undang Undang Republik Indonesta No 13 Tahun 2003.

- Uang Penghargaan berdasarkan Pasal 156 ayat (3) Undang Undang Republik Indonesia No 13 Tahun 2003.

- Uang penggantian hak atas cuti tahunan sesuai ketentuan 'Pasal 156 ayat (4) huruf a Undang Undang Republik Indonesia No 13 Tahun 2003.

- Uang penggantian hak atas perumahan, pengobatan dan perawatan sebesar $15 \%$ sesuai ketentuan Pasal 156 ayat (4) huruf c Undang-Undang Republik
Indonesia No 13 Tahun 2003.

- Upah selama proses pemutusan hubungan kerja. Apabila salah satu pihak atau paia pihak belum puas dengan putusan Pengadilan Hubungan Industrial, maka dapat mengajukan banding langsung kepada Mahkamah Agung.

Mekanisme proses penyelesaian perselisihian hubungan industrial atas dasar:

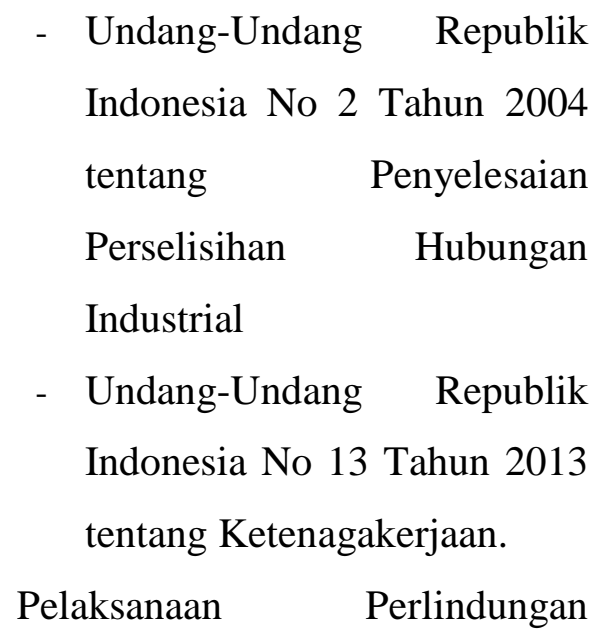
Hubungan Tenaga Kerja Outsourcing di Kota Semarang Berdasarkan Undang-Undang Republik Indonesia Nomor 13 Tahun 2003 Tentang Ketenagakerjaan.

Model outsourcing dapat dibandingkan dengan tentuk perjanjian pemborongan bangunan walaupun sesungguhnya tidak sama. Perjanjian pemborongan bangunan dapat disamakan dengan sistem kontrak biasa 
sedangkan outsourcing sendiri bukanlah suatu kontrak. Pekerja/buruh dalam perjanjian pemborongan bangunan dapat disamakan dengan pekerja harian lepas seperti yang diatur dalam Peraturan Menteri Tenaga Kerja NR : PER . 06 / MEN / 1985 tentang Perlindungan Pekerja Harian Lepas (PHL). PHL adalah pekerja yang bekerja pada pengusaha untuk melakukan suatu pekerjaan tertentu dan dapat berubah-ubah dalam hal waktu maupun volume pekerjaan dengan menerima upah yang didasarkan atas kehadiran pekerja secara harian. Sebagai contoh adalah kuli panggul yang mengangkat barang di pelabuhan Tanjung Priok. ${ }^{5}$

Perjanjian

bangunan akan terakhir antara pengusaha dengan pekerja apabila obyek perjanjian telah selesai dikerjakan. Misalnya pembangunan jembatan, dalam hal jembatan telah selesai maka masa bekerjanya pun menjadi terakhir kecuali jembatan tersebut belum selesai dikerjakan. Sedangkan dalam outsourcing masa bekerja akan berakhir sesuai dengan waktu yang telah disepakati antara pengusaha dengan

\footnotetext{
5 Toes Adi Widayaningrat. Wawancara Pribadi Ibid
}

perusahaan penyedia jasa tenaga kerja. ${ }^{6}$

Ditinjau dari segi pengusaha, adanya pemborongan pekerjaan dan atau penyedia jasa tenaga kerja, menerapkan perjanjian yang menguntungkan. Hal ini disebabkan oleh karena pengusaha dapat mengkonsentrasikan pemikirannya unhrk menangani core bisnisnya sedangkan pekerjaan-pekerjaan penunjang dapat diserahkan kepada pemborong. Dengan demikian pengusaha tidak perlu memiliki organisasi yang besar dengan jumlah tenaga kerja yang banyak. Demikian juga permasalahan ketenagakerjaan dapat dieliminir dengan adanya pusahaan lain yang menangani pekerjaan penunjang, dimana hubungan kerja pekerja langsung ditangani pemborong atau penyedia jasa tenaga kerja. $^{7}$

Ditinjau dari segi kepentingan pekerja, adanya pekerjaan pemborongan antara penyedia jasa tenaga kerja perlu adanya ketegasan hubungan kerja yang luas sehingga pemenuhan hak-hak pekerja berdasarkan peraturan perundang-undangan ketenagakerjaan jelas tanggungjawabnya. Untuk itu pekerja harus diikat dengan perjanjian

\footnotetext{
${ }^{6}$ Ibid

${ }^{7}$ Heru Budiman. Wawancara pribadi
} 
kerja dengan perusahaan yang. Hal ini penting karena dalam beberapa tahun terakhir ini pelaksanaan outsourcing banyak dilakukan dengan sengaja untuk menekan biaya pekerja (labor cost) tengan perlindungan dan syarat kerja yang diberikan jauh dibawah dari yang seharusnya diberikan sehingga sangat merugikan pekerja. ${ }^{8}$

Pelaksanaan outsourcing yang demikian dapat menimbulkan keresahan pekerja dan tidak jarang diikuti dengan tindakan mogok kerja, sehingga maksud diadakannya outsourcing seperti apa yang disebutkan di atas menjadi tidak tercapai, oleh karena terganggunya proses produksi barang dan jasa. Oleh karena itu, baik perusahaan maupun pekerja agar senantiasa dapat hidup bersama tanpa terjadi pertentangan kepentingan sebagai akibat dari pendapat ataupun pemikiran yang berbeda-beda, diperlukan pelaksanaan outsourcing yang sesuai dengan peraturan perundang-undangan yang berlaku, sebagai pedoman untuk berperilaku secara formal. $^{9}$

Atas dasar tersebut di atas, bahwa

${ }^{8}$ Toes Adi. Loc. it

9 Sendjun H. Manullang 1995, Pokok-Pokok Hukum Ketenagakerjaan Di Indonesia, Rineka Cipta,

Jakarta.hlm27 gangguan pelaksanaan outsoucing yang melindungi hak pekerja mungkin terjadi, apabila ada ketidakserasian antara nilai, kaidah, dan pola perilaku. Gangguan ini kaidah dan pola perilaku. Gangguan tersebut terjadi apabila ketidakserasian antara nilai-nilai yang berpasangan, yang menjelma didalam kaidah-kaidah bersimpang alur, dan pola perilaku tidak terarah yang mengganggu pelaksanaan tersebut diatas. Oleh karena itu, apakah pelaksanaan outsourcing melindungi hak pekerja bukan semata-mata pelaksanaan perundang-undangan (Law enforcement), namun juga ada faktor-faktor lain yang mempengaruhi, antara lain: ${ }^{10}$

1. Faktor hukumnya sendiri;

2. Faktor pelaksana atau yang menerapkan hukum; yaitu perusahaan dan pekerja;

3. Faktor kebudayaan, sebagai hasil karya, cipta, dan rasa yang didasarkan pada karsa manusia didalam pergaulan hidup.

Ketiga faktor di atas perlu mendapatkan perhatian dalam pelaksanaan outsourcing. Hal ini dimaksudkan agar pekerja benar-benar mendapatkan perlindungan yang layak sesuai dengan hak yang mereka miliki.

${ }^{10}$ Ibid, hal.31 
Disamping itu perlindungan bagi pekerja merupakan faktor yang sangat penting dalam rangka menciptakan keseimbangan dalam hubungan kerja, sehingga terwujudlah keadilan sosial yang merata di bidang ketenagakerjaan sesuai dengan landasan pancasila dan Undang-Undang Dasar Negara Republik Indonesia 1945.

Salah satu bentuk perlindungan dan kepastian hukum terutama bagi pekerja tersebut adalah melalui pelaksanaan dan penerapan perjanjian kerja. Perjanjian Kerja adalah perjanjian yang dibuat antara pengusaha dan pekerja yang memuat hak dan kewajiban pengusaha dan pekerja, termasuk syaratsyarat kerja, pengupahan, dan cara pembayaran. Dengan adanya perjanjian kerja diharapkan para pihak yang sepakat melakukan hubungan kerja lebih mengetahui hak dan kewajiban masing-masing pihak dan mengetahui sendiri apakah ia sudah melaksanakan perjanjian tersebut dengan baik atau ia melanggar perjanjian tersebut.

Perjanjian dibuat berdasarkan Pasal 1320 KUH Perdata yaitu mengenai syarat sahnya perjanjian, yaitu:

1. sepakat mereka yang mengikatkan diri;
2. kecakapan untuk membuat suatu perikatan:

3. suatu hal tertentu:

4. suatu sebab yang halal

Praktik sehari-hari outsourcing selama ini diakui lebih banyak merugikan pekerja/buruh, karena hubungan kerja selalu dalam bentuk tidak tetap/kontrak (PKWT), upah lebih rendah, jaminan sosial kalaupun ada hanya sebatas minimal tidak adanya job security serta tidak adanya jaminan pengembangan karir dan lain-lain sehingga memang benar kalau dalam keadaan seperti itu dikatakan praktik outsourcing akan menyengsarakan pekerja/buruh dan membuat kaburnya hubungan industrial. ${ }^{11}$

Hal tersebut dapat tejadi karena sebelum adanya UU Ketenagakerjaan No. 13 Tahun 2003, tidak ada satupun peraturan perundang-undangan dibidang ketengakerjaan yang mengatur perlindungan terhadap pekerja/buruh dalam melaksanakan outsourcing. Kalaupun ada, barang kali Permen Tenaga Kerja No. 2 Tahun 1993 tentang kesempatan kerja waktu tertentu atau (KKWT), yang hanya merupakan salah satu aspek dari ousourcing ${ }^{12}$

\footnotetext{
11 Setyo Bayu Nugroho. Wawancara Pribadi.

${ }^{12}$ Heru Budiman, Loc.it
} 
Kebanyakan dari para pekerja outsourcing adalah termasuk dalam perjanjian kerja untuk jangka waktu tertentu dan dimaksudkan untuk menutup kesulitan menentukan jenis pekerjaan tertentu yang dapat diselesaikan dalam waktu tertentu, misalnya mengenai pemborongan pekerjaan. Ini juga merupakan peluang yang dapat dimanfaatkan oleh perusahaan penyedia tenaga kerja dan para pemberi kerja agar mendapat tenaga murah dan berkualitas. ${ }^{13}$

Bilamana hak-hak pekerja ini tidak dipenuhi maka tuntutan pekerja mi dapat diajukan kepada Pegawai Perantara Dinas Tenaga Kerja dan mobilitas Penduduk setempat dengan permohonan agar dapat diberikan perantaraan agar pihak pemberi kerja memberikan hak-hak normatif dari pekerja outsourcing yang diberhentikan oleh pemberi kerja. Nasehat pegawai perantara ini dapat berupa anjuran agar pemberi kerja menjalin kembali hubungan kerja yang non diskriminatif dengan pihak pekerja atau dalam hal

13 J. Pareira Mandalangi, 1988,__Dari Hukum Perburahan ke Hukum Kerja dan Hukum Sosial, Dalam :

Percikan Gagasan Tentang Hukum, Fakultas Hutkum Unpar, Bandung., 1998,hal.64. pekerja diberhentikan maka diberikan hak-hak normatif seperti yang diberikan kepada pekerja tetap.

Bilamana anjuran ini tidak ditaati maka para pihak atau salah satu pihak bisa mengajukan kepada Pengadilan Hubungan Industrial melalui mekanisme gugatan yang biasanya memberikan keputusan dalam hal perselisihan pekerja dengan pemberi kerja dalam hal keputusan pemutusan hubungan kerja sebagai berikut $:^{14}$

a. Menetapkan putusnya hubungan kerja.

b. Memberikan pesangon sesuai ketentuan Pasal 156 ayat (2) Undang- Undang Republik Indonesia No 13 tahun 2003.

c. Uang Penghargaan berdasarkan Pasal 156 ayat (3) Undang Undang Republik Indonesia No 13 Tahun 2003.

d. Uang penggantian hak atas cuti tahunan sesuai ketentuan Pasal 156 ayat (4) huruf a Undang Undang Republik Indonesia No 13 tahun 2003.

e. Uang penggantian hak atas perumahan, pengobatan dan perawatan sebesar $15 \%$ sesuai ketentuan Pasal 156 ayat (4)

\footnotetext{
${ }^{14}$ Ekwan Priyanto. Loc.it
} 
huruf c Undang-Undang Republik Indonesia No 13 tahun 2003.

f. Upah selama proses pemutusan hubungan kerja.

Perlindungan hukum bagi pekerja pada dasarnya mengandung dua unsur yaitu perlindungan hukum preventif dan represif. Pada perlindungan hukum prefentif, tujuannya adalah menghindari sengketa. Salah satu wujudnya adalah dengan peran serta masyarakat terhadap peraturan perundang- undangan yang belum disahkan. Sayangnya hal ini belum berjalan di Indonesia, bahkan seringkah terjadi suatu undang-undang yang telah disahkan tidak pernah mempunyai naskah akademis. Kita kurang menganggap penting penerapan teori hukum dan filsafat hukum dalam suatu peraturan perundang-undangan. Peraturan sering hanya untuk memenuhi kebutuhan pragmatis dan hanya dianggap sebagai suatu proyek yang patut untuk di perebutkan dananya.

Pada Undang-Undang Republik Indonesia No. 13 Tahun 2003. mengenai konsep hukum hubungan kerja apabila ditinjau dari teori hukum mengandung banyak kesalahan. Pengertian hubungan kerja, berdasarkan ketentuan Pasal 1 anaka 15 Undang-Undang Republik
Indonesia No. 13 Tahun 2003 adalah hubungan antara pengusaha dengan pekerja/buruh berdasarkan perjanjian kerja, yang mempunyai unsur pekerjaan, upah, dan perintah. Lebih lanjut terdasarkan ketentuan Pasal 50 Undang-Undang Republik Indonesia No. '13 Tahun 2003, hubungan kerja terjadi karena adanya perjanjian kerja antara pengusaha dan pekerja/buruh. Hubungan kerja adalah hubungan hukum. Pasal 1 angka 15 jo Pasal 50 Pasal 66 Undang-Undang 'Repblik Indonesia No. 13 Tahun 2003 menjadi dasar hukumnya hubungan kerja. Dengan adanya dasar hukum itu maka timbulah peristiwa hukum.

Unsur perintah dalam hubungan kerja antara buruh dan majikan harus kita tinggalkan, sebagai negara hukum yang berdasarkan Pancasila kita wajib dan mampu menempatkan buruh pada kedudukan yang terlrormat (sederajat dengan majikan/pengusaha). Hubungan antara buruh dengan majikan /pengusaha bukan atas dasar perintah tetapi merupakan partner atau mitra kerja untuk menghasilkan barang atau jasa. ${ }^{15}$ Buruh selaku subyek hukum penerima kerja (werknemer) adalah tidak terada di bawah perintah majikan,

\footnotetext{
${ }^{15}$ Wijayanto Setiawan. Wawancara Pribadi
} 
tapi justru berkedudukan hukum sama dan sederajat dengan kedudukan hukum majikan sebagai layaknya pihak-pihak yang mengikat diri pada suatu perjanjian timbal balik. Subyek hukum dalam perjanjian kerja pada hakekatnya adalah subyek hukum dalam hubungan kerja. Yang menjadi obyek dalam perjanjian kerja adalah tenaga yang melekat pada diri pekerja. Atas dasar tenaga telah dikeluarkan oleh pekerja / buruh maka ia akan mendapatkan upah. ${ }^{16}$

Di dalam perjanjian kerja untuk waktu tertentu menurut Pasal 64 -66 Undang-Undang Republik Indonesia No. 13 Tahun 2003 dikenal pemborongan pekerjaan dan outsourcing. didasarkan ketentuan Pasal 64 Undang-Undang Republik Indonesia No. 13 Tahun 2003, perusahaan dapat menyerahkan sebagian pelaksanaan pekerjaan kepada perusahaan lainnya melalui perjanjian pemborongan pekerjaan atau penyediaan jasa pekerja/buruh yang dibuat secara tertulis. Menurut pendapat penulis terdapat kekeliruan dalam Pasal 64 terkaitan dengan pengertian outsourcing. Kalimat terakhir keliru, yaitu penyerahan penyedia jasa pekerja buruh yang dibuat secara tertulis atau

\footnotetext{
${ }^{16}$ Laica Marzuki
}

penyedia jasa buruh seharusnya ditiadakan diganti dengan perusahaan dapat menyerahkan sebagian pelaksanaan pekerjaan kepada perusahaan lainnya melalui perjanjian pemborongan pekerjaan yang dibuat secara tertulis. Outsourcing di dalam Pasal 64 menunjukkan bahwa ada 2 macam outsourcing yaitu outsourcing mengenai pekerjaannya yang dilakukan oleh pemborong, dan outsourcing mengenai pekerjaannya yang dilakukan oteh perusahaan jasa pekerja. Outsourcing yang pertama mengenai pekerjaan, konstruksi hukumnya yautu oleh main contractor yang membutuhkan pekerjaan pada sub kontraktor untuk melakukan pekerjaan yang disubkan oleh main contractor yang membutuhkan pekerja. Di sinilah sub kontraktor merekrut pekerja untuk mengerjakan pekerjaan yang disubkan oleh main contractor, sehingga ada hubungan kerja antara sub kontraktor dengan pekerjaannya. Perjanjian pemborongan pekerjaan atau penyediaan jasa pekerja/buruh harus memenuhi syarat sebagaimana dalam ketentuan Pasal 65 Undang-Undang Republik Indonesia No. 13 Tahun 2003, yaitu :

1. dilakukan secara terpisah dari kegiatan utama; 
2. dilakukan dengan perintah langsung, atau tidak langsung dari pemberi pekerjaan;

3. merupakan kegiatan penunjang perusahaan rccara keseluruhan; dan

4. tidak menghambat proses prcisi secara langsung

Kebijakan "outsourcing" yang tercantum dalam Pasal 64 - 66 UU Ketenagakerjaan telah mengganggu ketenangan kerja bagi buruh/pekerja yang sewaktu-waktu dapat terancam pemutusan hubungan kerja (PHK) \& men-downgrading-kan mereka sekedar sebagai sebuah komoditas, sehingga berwatak kurang protektif terhadap buruh/pekerja. Artinya UU Ketenagakerjaan tak sesuai dengan paradigma proteksi kemanusiaan yang, tercantum dalam Pembukaan UUD 1945 dan tertentangan dengan Pasal 27 ayat (2) UUD 1945.

Secara kelembagaan, usaha lainnya dalam Perdindungan tenaga kerja yang akan dilaksanakan adalah perbaikan peraturan dan pelaksanaan mengenai pengupahan seperti pembayaran upah pada waktunya, peembayaran upah sesuai dengan tingkat Kebutuhan Fisik Minimum (KFM), bilamana hal tersebut telah ditetapkan dan dapat dilaksanakan. ${ }^{17}$

Sejalan dengan usaha di bidang pengupahan adalah usaha untuk meningkatkan kesehatan, keselamatan dan kesejahteraan tenaga kerja. Adapun langkah-langkah dibidang tersebut adalah melaksanakan pengawasan yang lebih efektif dan efisien Semua peraturan perundang-undangan ketenagakerjaan yang sudah tidak sesuai dengan jiwa dan semangat Pancasila segera untuk diubah disesuaikan dengan alam dan kondisi bangsa Indonesia yaitu terdasar pada Parcasila dan UndangUndang Dasar 1945.

Di dalam Undang-Undang Republik Indonesia No. 13 Tahun 2003 tentang Ketenagakerjaan, perlindungan ini dimaksudkan untuk memberikan kepastian kewajiban pekerja yang berkaitan dengan norma kerja yang meliputi;
a. waktu kerja
b. mengaso
c. istirahat (cuti), dan
d. waktu kerja malam hari bagi pekerja wanita

\footnotetext{
17 Richaidus Eko Indrajit dan Richardus Djokopranoto.2003, Proses Bisnis Outsourcing Grasindo,
} 
Perjanjian outsourcing dapat disamakan dengan perjanjian pemborongan pekerjaan. Ketentuan outsourcing di dalam UUK 2003 diatur dalam Pasal 65 dan Pasal 66. Ketentuan lain mengenai. outsourcing diatur di dalam Kitab Undang-Undang Hukum Perdata buku ketiga bab 7A bagian keenam tentang Perjanjian Pemborongan Pekerjaan.

Dalam hal terjadi pemutusan hubungan kerja. pengusaha dapat dlwajibakan oleh P4-D atau P.N. (Dalam UU No.2 tahun 2W) 4 disebut Pengadilan Hubungan Industrial) untuk membayar uang pesangon (UP) dan atau uang penghargaan masa kerja (UPMK) dan uang penggantian hak (PH). Untuk UP menurut Pasal 156 (2) UUK paling sedikit:

a. Masa kerja kurang dari 1 tahun, 1 bulan upah

b. Masa kerja 1 tahun atau lebih tetapi kurang dari 2 tahun, 2 bulan upah

c. Masa kerja 2 tahun atau lebih tetapi kurang dari 3 tahun, 3 bulan upah

d. Masa kerja 3 tahun atau lebih tetapi kurang dari 4 tahun, 4 bulan upah

e. Masa kerja 4 tahun atau lebih tetapi kurang, dari 5 tahun, 5 bulan upah

f. Masa kerja 5 tahun atau lebih tetapi kurang dari 6 tahun, 6 bulan upah

g. Masa kerja 6 tahun atau lebih tetapi kurang dari 7 tahun, 7 bulan upah

h. Masa kerja 7 tahun atau lebih tetapi kurang dari 8 tahun, 8 bulan upah

i. Masa kerja 8 tahun atau lebih, 9 bulan upah

Sedangkan besarnya UPMK menurut Pasal 156 (3) UUK sebagai terikut:

a. Masa kerja 3 tahun atau lebih tetapi kurang dari 6 tahun, 2 bulan upah

b. Masa kerja 6 tahun atau lebih tetapi kurang dari 9 tahun, 3 bulan upah

c. Masa kerja 9 tahun atau lebih tetapi kurang dari 12 tahun, 4 bulan upah

d. Masa kerja 12 tahun atau lebih tetapi kurang dari 15 tahun, 5 bulan upah

e. Masa kerja 15 tahun atau lebih tetapi kurang dari 18 tahun, 6 bulan upah

f. Masa kerja 18 tahun atau lebih 
tetapi kurang dari 18 tahun, 7

bulan upah

g. Masa kerja 21 tahun atau lebih

tetapi kurang dari 24 tahun, 8

bulan upah

h. Masa kerja 24 tahun atau

lebih, 10 bulan upah

Untuk UPH dalam Pasal 156 (4)

UUK meliputi:

a. cuti tahunan yang belum diambil dan belum gugur;

b. biaya atou ongkos pulang untuk pekerja dan keluarganya ke tempat di mana pekerja diterima bekerja.

c. penggantian perumahan serta pengobatan dan perawatan ditetapkan sebesar $15 \%$ dari UP dan UPMK bagi yang memenuhi syarat;

d. hal-hal lain ditetapkan dalam perjanjian kerja peraturan perusahaan atau PKB.

Dengan perjanjian kerja dalam bentuk outsourcing, maka Pasal 156 (2) dan 156 (3) UUK, akan terkesan hanya menjadi hiasan dalam UUK UP dalam Pasal 156 (2) maksimum hanya untuk upah 2 bulan kerja. Sebab dalam praktek, sebagai berikut:

a. UP dalam Pasal 156 (2) maksimum hanya untuk upah 2 bulan kerja, sebab lama bekerja bervariasi 6 bulan, 1 tahun, dan 2 tahun.

b. UPMK Pasal -156 (3) tidak mungkin didapat oleh para pekerja outsourcing, karena pekerja yang di phk minimal telah bekerja selama 3 tahun untuk mendapatkan UPMK 2 bulan upah.

c. UPH seperti biaya atau ongkos pulang untuk pekerja dan keluarganya ke tempat di mana pekerja diterima bekerja, sangat jarang untuk didapat pekerja; sebab lamaran penerimaan dan seleksi dilakukan di kota tempat perusahaan. Apalagi jenis pekerjannya tidak memerlukan keahlian khusus.

Hak pekerja outsourcing terhadap jamsostek, tidak-jelas disebutkan di dalam perjanjian kerjanya, pekerja outsourcing paitr PT. Jamsostek mencantumkan hak untuk mendapatkan jaminan dari 4 program jaminan, yaitu: 1. program jaminan kecelakaan kerja, 2. program jaminan kematian, 3. program jaminan tabungan hari tua, 4 program jaminan pemeliharaan kesehatan. 
Namun yang menjadi pertanyaan tentang hak terhadap program jaminan tabungan hari tua. Sebab perjanjian kerja outsourcing waktunya paling lama 2 tahun. $^{18}$

Upah yang diperoleh pekerja outsourcing biasanya dalam bentuk Upah Minimum Propinsi (UMP). Walaupun ada kenaikan upah setiap tahun, hal tersebut dikarenakan adanya perubahan Peraturan Daerah tentang UMP untuk penyesuaian saja. Kehendak untuk mendapatkan upah yang layak, jauh dari harapan para pekerja outsourcing. Untuk pekerja tetap saja telum tentu mendapat upah yang layak. Namun paling tidak ada kreteria dalam penentuan skala upah, misalnya melalui penunjangan upah. ${ }^{19}$

Demikian juga terhadap tabungan pensiun tidak mungkin akan didapatkan oleh pekerja outsourcing, walaupun mereka selalu memperpanjang pekerjaan dari waktu ke waktu. Oleh karena itu perlu ada ketegasan dalam peraturan perundang-undangan bahwa setelah kontrak pertama atau kedua berakhir, pekerja outsourcing harus diangkat menjadi pekerja tetap pada perusahaan

\footnotetext{
18 Richaidus Eko Indrajit dan Richardus

Djokopranoto.Loc.Cit,hlm.32

19 Setyo Bayu. Loc.it
}

tersebut. $^{20}$

\section{Hambatan dalam Pelaksanaan Perlindungan Hukum Tenaga Kerja Outsourcing di Kota Semarang Berdasarkan Undang-Undang} Republik Indonesia Nomor 13 Tahun 2003 Tentang Ketenagakerjaan

Kebijakan hubungan industrial bertujuan untuk menciptakan hubungan industrial yang harmonis, dinamis, berkeadilan dan bermartabat dalam perusahaan yang senantiasa berkembang. Untuk dapat mencapai tujuan tersebut, kebijakan hubungan industrial harus mampu menjawab tantangan yang berkembang sesuai dengan dinamika hubungan industrial. Kondisi hubungan industrial di suatu negara sangat rentan dengan perubahan karena dipengaruhi oleh beberapa faktor baik eksternal maupun internal ketenagakerjaan yaitu : ${ }^{21}$

1. Kondisi ketenagakerjaan yang bersifat struktural yaitu tingginya angka pengangguran, rendahnya kualitas angkatan kerja dan tingkat kesejahteraan tenaga kerja.

\footnotetext{
${ }^{20}$ Ibid

${ }^{21}$ Ekwan Priyanto,Loc.it
} 
2. Perubahan lingkungan strategis yang meliputi semua aspek kehidupan dalam berbangsa dan bernegara, diawali dengan krisis ekonomi yang membawa penurunan kinerja usaha, menyebabkan semakin banyaknya PHK yang kemudian menuntut perlunya reformasi di bidang Hubungan Industrial yang ditandai dengan tuntutan terhadap peningkatan perlindungan tenaga kerja dan perbaikan syarat-syarat kerja serta penerapan kebebasan berserikat sehingga terjadi pembahan yang sangat signifikan dari jumlah serikat pekerja/buruh yaitu dari single union menjadi multi union.

3. Globalisasi, antara lain ditandai dengan tuntutan yang sangat kuat diberlakukannya Standard yang bersifat universal sehingga setiap perlakuan yang mengabaikan hak-hak dasar pekerja sebagaimana yang tercantum dalam Konvensi ILO akan selalu menjadi perhatian masyarakat dunia. Sementara di sisi lain, perusahaan dituntut untuk meningkatkan efisiensi dan produktivitas dalam menghadapi kompetisi global. Oleh karena itu dapat dimengerti kemudian muncul bentuk-bentuk baru pengelolaan usaha yang mengisyaratkan fleksibilitas hubungan kerja seperti sistem kontrak, outsourcing atau tailoring order.

Segala fenomena pembahan yang terjadi dalam konteks pelaksanaan hubungan industrial harus kita cermati bersama. Maraknya unjuk rasa merupakan indikasi bahwa praktek hubungan industrial yang berlangsung, sekarang ini, perlu untuk dikaji kembali tentang efektifitas pelaksanaannya. Beberapa peristiwa unjuk rasa, sering pula diwarnai dengan tindakan yang bersifat anarkis dan bukan pula tidak mungkin dapat ditumpangi kepentingan politik.

Permasalahan hubungan industrial pada hakekatnya adalah tantangan yang dihadapi dan timbul akibat perubahan 
nilai, antara lain meliputi : $:^{22}$

1. Pelaksanaan hubungan industrial dihadapkan pada kewajiban untuk memberikan kontribusi menciptakan iklim usaha yang kondusif untuk investasi

2. Fenomena reformasi, kebebasan berserikat, demokratisasi, pelaksanaan HAM, supremasi hukum dan Otoda berdampak pada kondisi hubungan industrial di perusahaan.

3. Fenomena globalisasi, penerapan Standard internasional, meningkatkan daya saing, pengusaha menempuh manajemen efisien dan produktif sehingga mempunyai kecenderungan untuk memiliki bentuk yang fleksibel dalam hubungan kerja.

4. Needs, (kebutuhan manusia) yang senantiasa meningkat.

5. Peran dan fungsi sarana hubungan industrial yang belum optimal searti 'PP. PKB, LKS Bipartit. LKS Tripartit. Peran SP/SB. Assosiasi Pengusaha, Peraturan Ketenagakerjaan dan Lembaga Penyelesaian
Perselisihan

Hubungan

Industrial.

Pelaksanaan hubungan kerja dalam outsourcing diatur dalam 'Pasal 65 ayat (6) dan (7) dan Pasal 66 ayat (2) dan (4) Undang-Undang Republik Indonesia No. 13 Tahun 2003. Peraturan tersebut tehrm menjawab semua permasalahan outsourcing yang begitu luas dan kompleks. Namun setidak-tidaknya dapat memberikan perlindungan hukum terhadap pekerja/buruh terutama yang menyangkut syarat- syarat kerja, kondisi kerja serta jaminan sosial dan perlindungan kerja lainnya serta dapat dijadikan acuan dalam menyelesaikan apabila terjadi permasalahan.

Pada keadaan tertentu sangat sulit untuk mendefinisikan/ menentukan jenis pekerjaan yang dikategorikan penunjang. Hal tersebut dapat terjadi karena perbedaan persepsi dan adakalanya juga dilatarbelakangi kepentingan yang diwakili untuk memperoleh keuntungan dari kondisi tersebut. Disamping itu bentuk-bentuk pengelolaan usaha yang sangat bervariasi dan beberapa perusahaan multi nasional dalam era globalisasi membawa bentuk baru kemitraan 
usahanya, menambah semakin talum. kompleknya kerancuan tersebut.

Kehendak untuk mendapatkan upah yang layak, jauh dari harapan para

\section{Penutup}

\section{Kesimpulan}

Perlindungan hukum bagi pekerja pada dasarnya mengandung dua unsur yaitu perlindungan hukum preventif dan represif. Pada perlindungan hukum prefentif, tujuannya adalah menghindari sengketa. Salah satu wujudnya adalah dengan peran Serta masyarakat terhadap peraturan perundang- undangan yang telah disahkan. Sayangnya hal itu belum berjalan di Indonesia, bahkan seringkali terjadi suatu Undang-Undang yang telah disahkan tidak pernah mempunyai naskah akademis.

Hak pekerja outsourcing terhadap jamsostek, tidak jelas disebutkan di dalam perjanjian kerjanya. Pekerja outsourcing, pada PT. Jamsostek mencantumkan hak untuk mendapatkan jaminan dari 4 program jamsostek, yaitu: 1. program Jaminan kecelakaan kerja, 2. program jaminan kematian, 3. program jaminan tabungan hari tua, 4 program jaminan pemeliharaan kesehatan. Namun yang menjadi pertanyaan tentang hak terhadap program jaminan tabungan hari tua. Sebab perjanjian kerja outsourcing waktunya paling lama 2 pekerja outsourcing. Untuk pekerja tetap saja belum tentu mendapat upah yang layak. Namun paling tidak ada kretaia dalam penentuan skala upah, misalnya melalui penjenjangan upah. Demikian juga terhadap tabungan pensiun tidak mungkin akan didapatkan oleh pekerja outsourcing, walaupun mereka selalu memperpanjang perjanjian dari waktu ke waktu. Oleh karena iu perlu ada ketegasan dalam peraturan perundangundangan bahwa setelah kontrak pertama atau kedua berakhir, pekerja outsourcing hanrs diangkat menjadi pekerja tetap pada perusahaan tersebut.

Dalam hal terjadi pemutusan hubungan kerja, pengusaha dapat diwajibkan oleh P4-D atau p .N. (Dalam UU No.2 tahun 204 disebut Pengadilan Hubungan Industrial) untuk membayar uang pesangon (UP) dan atau uang penghargaan masa kerja (UPMK) dan uang penggantian hak $(\mathrm{PH})$.

Hambatan-hambatan yang terjadi dalam Pelaksanaan Perlindungan hukum bagi tenaga kerja outsourcing berdasarkan Undang-Undang Nomor 13 tahun 2003 Tentang Ketenagakerjaan. Kondisi hubungan industrial di suatu 
negara sangat rentan dengan perubahan karena dipengaruhi oleh beberapa faktor baik eksternal maupun internal ketenagakerjaan yaitu:

a. Kondisi ketenagakerjaan yang bersifat struktural yaitu tingginya angka pengangguran, rendahnya kualitas angkatan kerja dan tingkat kesejahteraan tenaga kerja.

b. Perubahan lingkungan strategis yang meliputi semua aspek kehidupan dalam berbangsa dan bernegara diawali dengan krisis ekonomi yang membawa penurunan kinerja usaha menyebabkan semakin banyaknya PHK yang kemudian menuntut perlunya reformasi dibidang Hubungan Industrial yang ditandai dengan tuntutan terhadap peningkatan perlindungan tenaga kerja dan perbaikan syarat-syarat kerja serta penerapan kebebasan berserikat sehingga terjadi perubahan yang sangat signifikan dari jumlah serikat pekerja/buruh yaitu dari single union menjadi multi union.

c. Globalisasi, antara lain ditandai dengan tuntutan yang sangat kuat diberlakukannya Standard yang bersifat universal sehingga setiap perlakuan yang mengabaikan hak-hak dasar pekerja sebagaimana yang tercantum dalam. Konvensi ILO akan selalu menjadi perhatian masyarakat dunia. Sementara di sisi lain, perusahaan dituntut untuk meningkatkan effisiensi dan produktivitas dalam menghadapi kompetisi global Oleh karena itu dapat dimengerti kemudian muncul bentuk-bentuk baru pengelolaan usaha yang mengisyaratkan fleksibilitas hubungan kerja seperti sistem kontrak, outsourcing atau tailoring order.

d. Needs (kebutuhan manusia) yang senantiasa 
meningkat.

e. Peran dan fungsi sarana hubungan industrial yang belum optimal seperti PP, PKB, LKS Bipartit, LKS Tripartit, Peran SP/SB, Assosiasi Pengusaha, Peraturan Ketenagakerjaan dan. Lembaga Penyelesaian Perselisihan Hubungan Industrial.

Salah satu usaha penyelesaian hambatan dalam pelaksanaan perlindungan hukum bagi tenaga kerja outsourcing berdasarkan Undang-Undang Nomor 13 tahun 2003 Tentang Ketenagakerjaan ialah dengan terlaksananya sistem pengawasan ketenagakerjaan yang dianut adalah "Integrated Impection System" atau yang disebut dengan sistem terpadu. Sistem terpadu ini didasarkan pada Peraturan Menteri Tenaga Kerja No. ERT. 3/MEN/1984. keterpaduan yang dilaksanakan meliputi pendidikan pengawasan ketenagakerjaan, operasional lapangan dan ketatalaksanaan.

Pelaksanaan hubungan industrial yang harmonis merupakan kunci strategis agar ketenangan kerja dan berkembangnya perusahaan terwujud (,industrial harmony and econonuc develoment) ada tiga sisi penting yang dapat dijadikan indikator menuju kondisi hubungan industrial yang harmonis di perusahaan.

Setiap perselisihan hubungan industrial wajib diupayakan penyelesaiannya terlebih dahulu melalui perundingan bipart it dan jika perundingan mencapai hasil dibuatkan persetujuan bersama (PB) dan apabila tidak tercapai kesepakatan maka dapat dilakukan upaya Mediasi, Konsiliasi atau Arbitarse.

\section{Saran}

Setelah melakukan penelitian, maka saran yang dapat disampaikan adalah sebagai berikut:

1. Perlu adanya Sosialisasi tentang tenaga kerja outsourcing yang terdapat dalam Undang-Undang Nomor. 13 tahun 2003 tentang Ketenagakerjaan dan peraturan-peraturan pendukungnya harus terus dilaksanakan, agar semua pihak dapat mengetahui dan memahami maksud dari ketentuan dimaksud.

2. Perlu adanya peralatan 


$\begin{array}{lll}\begin{array}{l}\text { pendukung } \\ \text { pelaksanaan } \quad \text { sosialisasi }\end{array} & \begin{array}{l}\text { para pengusaha yang masih } \\ \text { melanggar ketentuan yang }\end{array} \\ \text { tentang tenaga kerja } & \text { berkaitan } & \text { dengan } \\ \text { outsourcing yang diatur dalam } & \text { Undang-Undang Nomor 13 } \\ \text { Undang-Undang Nomor 13 } & \text { Tahun 2003 ditindak sesuai } \\ \text { tahun 2003, seperti brosur, } & \text { dengan undang- undang } \\ \text { alai peraga dan menjangkau } & \text { dimaksud } & \text { secara } \\ \text { unit-unit di daerah-daerah } & \text { proporsional; } \\ \text { terpencil; } & & \end{array}$

3. Perlu kejelasan status pegawai DAFTAR PUSTAKA pengawas, apakah sebagai pegawai pusat yang ditempatkan ke daerah atau pegawai pemerintah daerah, dengan konsekuensi adanya pengisian tugas pengawas oleh pegawai yang belum berpengalaman sebagai pengawas sehingga dapat mengawasi dengan tegas dan benar tentang penggunaan tenaga kerja outsourcing di perusahaan.

4. Perlu penegakkan ketentuan yang ada yang mengatur tentang tenaga kerja outsourcing yang terdapat dalam Undang-Undang Nomor 13 Tahun 2003 tentang Ketenagakerjaan secara konsisten dan konsekuen, artinya terhadap Asshiddiqie Jimly, 1998, Pembangunan Hukum Nasional di Abad Globalisasi, Balai Pustaka., Jakarta.

,1996, Pergulan Peran Pemerintah dan Parlemen dalam Sejarah: Telaah Perbandingan Konstitusi Berbagai Negara,UI-Press, Jakarta , 2000, "Penataan Kembali Bentuk dan Tato Urut Peraturan PerundangUndangan Republik Indonesia", makalah Seminar Nasional tentang Perubahan Undang- Undang Dasar 1945, Bandar Lampung: Sekretariat 
Jenderal MPR-R1 dan

Fakultas Hukum Universitas Indonesia, 24-26 Maret, 2000.

1999, "Reformasi Hukum

Nasional", makalah seminar

Kelompok Kerja Nasional

Reformasi Hukum Menuju

Masyarakat Madani,

Sekretariat Negara, Jakarta

Bisri, I. 2004, Hukum Indonesia:

Prinsip-prinsip dari implementasi hukum di

Indonesia. PT.Grafindo

Persada, Jakarta..

Cooter Robert, 1998, Law and Economic, Scot Forestran \& Co. Illinois.

Didi Nazmi Yunas, 1992,, Konsepsi Negara Hukum, Angkasa Raya,

Gunarto Suhardi, 2006, Perlindungan Hukum Bagi Para Pekerja Kontrak Outsourcing,

Universitas Atma Jaya, Yogyakarta.

\begin{tabular}{|c|c|c|}
\hline \multirow[t]{4}{*}{ Imam } & Soepomo, $\quad 1980$, & Hukum \\
\hline & Perburuhan, & Bidang \\
\hline & Hubungan & Kerja, \\
\hline & Djambatan. & \\
\hline
\end{tabular}

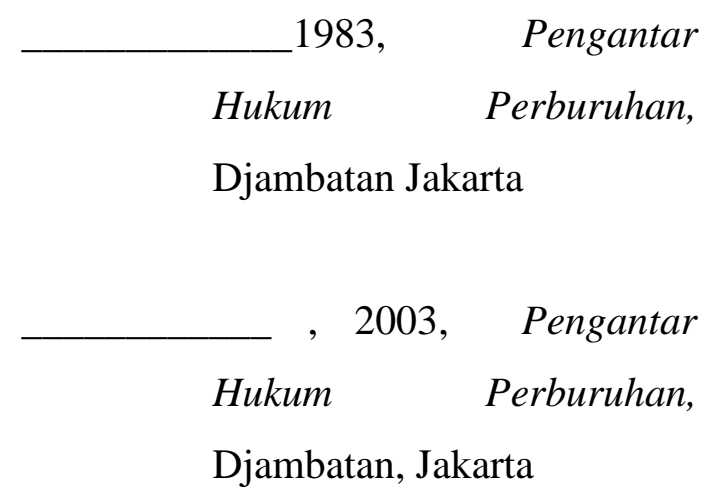

Iman Sjahputra Tunggal, 2002, Ketenagakerjaan Indonesia, Cet. ke-1, Harvarindo,

Kelsen, H.2002. Essay in legal \& moral philosophy. (Terj. PT Alumni bekerja sama dengan Arief Sidharta). PT Alumni, Bandung.

J. Pareira Mandalangi, 1988,__Dari Hukum Perburahan ke Hukum Kerja dan Hukum Sosial, Dalam : Percikan Gagasan Tentang Hukum, Fakultas Hutkum Unpar, Bandung.

Levinson, Sanford, 1988, The 


$\begin{array}{ll}\text { Constitutional Faith, } & \text { tahun 1986. Diterjemahkan } \\ \text { Princeton University Press, } & \text { dan diberi kata pengantar } \\ & \text { ofeh Trevor j. Saunders. }\end{array}$

Lubis, Solly, 24-26 Maret, 2000,

$\begin{array}{lll}\text { "SumberHukum Perangkat } & \text { Chainur Arrasjid, 2000, Dasar-dasar } \\ \text { dan Peringkat } & \text { Peraturan } & \text { Ilmu Hukum, Sinar Grafika. }\end{array}$

Hukum makalah Seminar

Nasional Perubahan UUD

1945, Bandar Lampung:

Richaidus Eko Indrajit dan Richardus

Sekretariat Jenderal

Djokopranoto.2003, Proses

MPR-R1 dan Fakultas

Bisnis Outsourcing

Hukum Universitas

Indonesia.

Ronny Hanitijo_Soemitro, 1990,Metode Penelitian Hukum dan

Mohd. Syaufi' I dan Saparyati, SH, 2000.

Jurimetri, Ghalia Indonesia,

Pengaturan Pemutusan Jakarta..

Hubungan Kerja di

Perusahaan Swasta, Badan

Usaha Milik Negara,

Satjipto Rahardjo, 2000, Ilmu Hukum,

Perusahaan Pelayanan

Alumni, Bandung.

Swasto dan Lembaga

Satjipto Rahardjo, 1999, Hukum dan Tertentu. LP3ES Jakarta.

Masyarakat, Angkasa, Bandung.

Mubarak, Z,. et al. 2008. Mata kuliah

pengembangan kepribadian

terintegrasi: buku ajar II

manusia, akhlak, budi

pekerti \& masyarakat.

Sendjun H. Manullang 1995,

Pokok-Pokok Hukum
Ketenagakerjaan Di
Indonesia, Rineka Cipta,
Jakarta

Jakarta: Lembaga Penerbit

FEUI

Soedarjadi, 2008, Hukum

Ketenagakerjaan di Indonesia, Pustaka

Plato: The Laws, Penguin Classics, edisi Yustisia, Yogjakarta. 
Soerjono soekanto, 2002, Penelitian

Hukum Normal Suatu

Tinjauan Singkat, Raja

Grafindo, Jakaita.

Suhardi Gunarto, 2002, Peranan Hukum

Dalam Pembangunan

Ekonomi,Universitas

Atmajaya. Yogyakarta.

Ultrecht, 1962, Pengantar Hukum Administrasi Negara Indonesia, Ichtiar, Jakarta

Wolhoff, G.J., Pengantar Ilmu Hukum Tata Negara Republik Indonesia, Timun Mas, Jakarta.

Wr. Sitanggang, 2001, Hak Mogok dan Penutupan Perusahaan, Rajawali Press. Jakarta

Yamin, Muhammad, 1959, Naskah Persiapan Undang-Undang Dasar 1945, Jajasan Prapantja, Jakarta. 